\title{
THE PLANNING OF HUMAN RESOURCES (STATE APPARATUS) QUALITY IMPROVEMENT IN THE PERSPECTIVE OF GOVERNANCE: A STUDY ON REGIONAL EMPLOYMENT BOARD OF MALANG
}

\author{
Kurube Elisa Hendrik*, Hakim Abdul, Sujarwoto \\ Master's Degree Program in Public Administration, \\ Faculty of Administrative Science, University of Brawijaya, Indonesia \\ ${ }^{*}$ E-mail: elisahendrikk@gmail.com
}

\begin{abstract}
The main focus of this study is the Planning of Quality Improvement of Human Resources (State Apparatus) in the Perspective of Good Governance, A Study on the Program of State Apparatus Capacity Improvement in Regional Employment Board of Malang. This study used a qualitative research (naturalistic) with a research strategy of observation. The purpose of this study is to review and analyze the planning of human resources quality improvement in the perspective of good governance in the Regional Employment Board of Malang; to determine the supporting factors and improve the quality of resources in the planning of human resources quality improvement in the perspective of good governance in the Regional Employment Board of Malang. The development of employees' capacity carried out by the Regional Employment Board of Malang is intended to strengthen the organization and as an effort to establish a system of good governance. Given the number of local officials who must be served and managed by the employees of Regional Employment Board, this requires an effort of capacity building through the planning of human resources quality improvement in a systematic way and in accordance with the principles of good governance characteristics.
\end{abstract}

\section{KEY WORDS}

State apparatus, resources, planning, governance.

Given the need to improve the quality of public services and performance within the organization, qualified Human Resources (HR) is one of the important factors at the Regional Government Institutions. With a clear planning of developing human resources quality, the organization can achieve its goals more effectively and efficiently with optimal performance in achieving good governance. According to the World Bank (in Wahab, 2002: 34), it is defined that good governance is an implementation of a solid and responsible development management that is in line with the principles of democracy and efficient market, the avoidance of investment funds misallocation, and the prevention of corruption both political and administrative, running a budget discipline and the creation of legal and political framework for the growth of business activities. Meanwhile, the United Nations Development Programme UNDP (in Mardiasmo, 2009) has given the sense that good governance is understood as an implementation of political authority, economic, and administrative management processes on various levels of public affairs in a country.

Sedarmayanti (2009: 103) further said that improving the quality of human resources apparatus is usually done with education and training. Education and training is a process of transformation in improving the quality of human resources apparatus where one of the specific objectives of education and training is to improve knowledge, skills, and attitudes to be able to perform professional duties based on the personality and ethics of civil servants according to the needs of the organization.

Based on previous research by Artika (2014, p.6) and Prasetia (2014, p.4), there are some problems related to the role of Regional Employment Board of Malang Regency in implementing its function. On the other hand, the demand for good governance is increasingly urgent. Therefore, the Regional Employment Board of Malang Regency is required to always strive to develop the ability and improve the performance of its internal 
employees to be more committed and professional in every excellent service from all aspects.

The development of employees' capacity carried out by the Regional Employment Board of Malang is intended to strengthen the organization and as an effort to establish a system of good governance. Given the number of local officials who must be served and managed by the employees of Regional Employment Board, this requires an effort of capacity building through the planning of human resources quality improvement in a systematic manner and in accordance with the principles of good governance characteristics.

\section{LITERATURE REVIEW}

The Improvement and Development of Human Resources (Peningkatan dan Pengembangan Sumber Daya Manusia or PPSDM) in government agencies should be able to see the whole dimensions of outer and inner life (Sulistyani, 2004: p.35). In her book, Sulistyani also described two basic orientations in PPSDM that must be applied in a balanced way, among others:

- Leads to the performance quality of government officials or employees that are closely related to the efforts of achieving productivity and performance of the bureaucracy;

- Leads to the preparedness of the mental and physical state of the employee which is closely related to the overall level of human dignity and prestige appreciation.

According to Tohardi (2002: 20), there are several factors that could affect the quality improvement of human resources including the level of education, discipline, work ethic, and motivation. In practice, these principles are a prerequisite for the creation of good governance. The government will be able to carry its functions within the framework of good governance when there is a system of public administration that is in line with the presence of qualified human resources. This happens because most of the principles contained in the good governance framework have not been implemented in the performance of the apparatus especially in the implementation of public services. The principles of good governance that have not been implemented are the principle of transparency, equality, accountability, effectivity and efficiency, and responsiveness. Meanwhile, the principles that have been implemented at the sub-district level consisted of the principles of participatory, law enforcement, and future insights. Thus, it needs to improve the quality of human resources in the perspective of good governance so that the public service is expected to be implemented properly.

\section{METHODS OF RESEARCH}

This study used a qualitative approach (naturalistic) with a research strategy of observation. The focuses of this research are:

1. Planning of the quality of human resources apparatus, viewed from:

- Employment planning

- Program planning

- Program planning follows the development of the staffing.

- Program planning includes coordinating programs.

- HR analysis accompanies the organizational strategy preparation of Regional Employment Board of Malang

- The classification of HR apparatus on Regional Employment Board of Malang

- Produce an alternative program to reach the goals

- Evaluate the alternative program

- Implement an integrated set of programs based on HR objectives achievement as effective as possible

2. Factors that support and inhibit the planning of human resources quality improvement are viewed from; 
- Supporting factors: institutional that handle particular field; regulations that underlie the program implementation and some activities;

- Inhibiting factors: nonoptimal use of information technology in the employment data management; less qualified human resources; less adequate budget.

In this research, the location of the research is Regional Employment Board in Malang. The data source of this research comes from informants, events, and documents. The technique of data collection is done through the interview, observation, and documentation. Next, in analyzing the research data, researchers refer to the theory of (Daymon and Holloway, 2008, p.369):

1. Sorting and selecting data by editing. This step is related to the selection of data that has been obtained and the data is then edited until it can be understood.

2. Providing the code in the selected data (coding) (Daymondan Holloway, 2008, h.369)

3. Giving interpretation of meaning to the data that has been selected (Daymondan Holloway, 2008, h.369)

\section{RESULTS AND DISCUSSION}

The Planning of Human Resources Quality Improvement in the Regional Employment Board of Malang. The demand for public services in this globalization era is the hope and desire of the community and, at the same time, is a picture of the quality of government bureaucracy performance that has wide implications for various aspects. The efforts in improving the service performance of the personnel on an ongoing basis continue to be improved to encourage the creation of a conducive situation in the implementation of apparatus management services that will provide welfare to the community.

An improvement on the service performance is a strategic decision of the Regional Employment Board of Malang that has wide implications in every aspect to the continual improvement as well as the services that are always focused on the customer either in whole State Civil Apparatus (Aparatur Sipil Negara or ASN) that existed on the Regional Work Unit (Satuan Kerja Perangkat Daerah or SKPD) that existed between the Government of Malang Regency and the community. Sulistiyani (2009: p.122) argued that human resources planning is designed to ensure that the organization's needs for employees can be met consistently and appropriately. In the theory, it is stated that the planning is based on the elements that build it. As known, "Planning of the quality improvement of human resources (apparatus)" is a system formed from the elements of planning, quality improvement, human resources, and apparatus.

Staff Planning on Regional Employment Board of Malang. Staff planning on the Regional Employment Board of Malang refers to the national policy that is on the macro target of development and on the priority of regional development with the enactment of Law Number 5 of 2014 on State Civil Apparatus by referring to the systemic bureaucracy reform which includes institutional improvement. The management of bureaucratic resources includes various levels ranging from the structure to the mindset and culture of bureaucracy. The staff planning process on the Regional Employment Board of Malang is done by paying attention to the Law Number 25 of 2004 on National Development Planning System.

The planning steps undertaken by the Regional Employment Board of Malang in preparing the staffing formation can be seen from the strength of ASN each year. From the formation, it can be known the total number of employees, the employees who prepare for retirement, and the needed employees which then are brought to be reported to the central office. The Regional Employment Board of Malang also performs the planning in accordance to the long-term needs, balance, procurement, and selection or dismissal as well as planning for employee development.

Program planning on Regional Employment Board of Malang. The program preparation of the Regional Employment Board of Malang refers to the Regional Medium-Term Development Plan (Rencana Pembangunan Jangka Menengah Daerah or RPJMD) principal agenda of Malang by optimizing the performance of the bureaucracy and public service. As mentioned earlier by Sjafrizal (2014: h.341), regional development is basically the action of 
the program (intervention) which is carried out by local government in order to realize the direction of the policy that has been set in the planning of concerned regional development.

The compulsory programs and supporting programs in Regional Employment Board of Malang are as follows:

1. Compulsory programs: Education Program; Human Resources (State Apparatus); Capacity Improvement Program; Development and Parenting Development Program;

2. Supporting programs: Office Administration Services Program; Infrastructure Improvement Program; Discipline Enhancement Program; Human Resources (State Apparatus) Capacity Improvement Program; Performance and Financial Reporting System Improvement Program.

Program Planning Follows the Development of the Staffing on Regional Employment Board of Malang. The development of personnel plan on Regional Employment Board of Malang to conduct programs and activities that can support national development policies as priority with a suitability to its area and support the mainstreaming of gender and child protection in the region, Regional Employment Board implemented an Education of Service program in 2016in which this has been like a routine for the office. The program is arranged as follows:

1. Routine activities: starting from the provision of correspondence services to the preparation of year-end financial statements.

2. Compulsory Business Activities: starting from Structural Gap Up to Monitoring, Evaluation, and Reporting.

Human Resources Analysis Accompanied by Organization Strategy on Regional Employment Board of Malang. The analysis of human resources on Regional Employment Board of Malang is seen from the service performance that is based on the main task and function based on Main Performance Indicator. Main Performance Indicator is done based on the mission of Regional Employment Board of Malang that is to expand innovation and bureaucratic reform for clean and effective governance in a poor district.

The Classification of State Apparatus on Regional Employment Board of Malang. The classification of human resources (state apparatus) on the Regional Employment Board of Malang. According to Sulistiyani (2009: p159), the classification of employees is about the categorization of employees, position according to the type of employee and skills, and that knowledge and skills required. In implementing the programs and activities, such resources are needed in order to realize the vision and mission of the area. Human Resources (State Apparatus) of the Regional Employment Board of Malang is a unity of individuals conducting cooperation in the activities to achieve the goals and objectives. To achieve success in achieving the goal, it requires capable, skilled, disciplined, and competent human resources.

Generate Alternative Programs to Achieve Goals. Produce an alternative program to achieve the intended purpose. Regional Employment Board in the interview said that the implementation of alternative programs is carried out in accordance with the goals and objectives to improve the quality of service in the field of personnel.

Sulistiyani (2009: p.137) suggested that in order to achieve the determined goals, it needs to generate alternative programs based on HR model. The strategic objectives and targets of the Regional Employment Board can be set in the annual work plan. In 2017, the work plan of the Regional Employment Board can be formulated in 1 (one) objective of improving the quality of service in the field of personnel with 2 (two) targets.

The Regional Employment Board of Malang conducted an alternative program analysis to achieve the strategic objectives gradually in the long-term, medium-term, and short-term plan in the form of priority programs in the annual work plan. According to Riyadi (2004: p.214), he argued that the analysis of alternative and priority setting is a technique to examine alternative programs that can be arranged to achieve certain desired conditions (goals), then, the priority of the determined program is implemented as a gradual action to achieve the objectives.

Evaluating Alternative Programs. Evaluation is seen as a way to obtain information as a decision-making material. Evaluators work with decision makers to identify the decision and collect information about the relative losses and rewards of each alternative decision to 
obtain the best decision. Evaluating alternative programs in accordance with the research of Sulistiyani (2009: p.138) pointed out that this activity is generated based on four criteria: the likelihood of success, the anticipated cost, the technical feasibility of the action, and the possible impact of the action on other parts of the organization.

Implementing an Integrated Set of Programs Based on Achieving Human Resource Goals Effectively. Implement an integrated set of programs based on achieving human resources objectives as efficiently as possible. Sjafrizal (2014: p.65) believed that the program can be further detailed in the form of one or more concrete, specific, and interconnected activities either at a particular location or spread over several locations.

Supporting and Inhibiting Factors in the Planning of Human Resources Quality Improvement.

Supporting Factors:

Institution. With the establishment of institutions in Malang including the Regional Employment Board, this gives an impact on the improvement of personnel management. Apparatus as the executing element in Malang governance should be noticed so that it will give impact to the work motivation and spirit to give service to society. The needs and rights of the apparatus must be well managed.

The existence of legislation. As stipulated in Article 55 of Law Number 5 The year 2014, management apparatus is one of the career development of employees. The Law mandates that the management of personnel should pay attention to the career of apparatus as an effort to increase the spirit and motivation of work to carry out services to the community. This also provides obligations to government organizations including the Regional Employment Board to perform the obligations in planning the quality improvement of the apparatus. The implementation of affairs and authority of the Regional Apparatus Organization must be based on legislation as its legal operation. Regional Employment Board of Malang as Regional Apparatus Organization in the Government of Malang Regency is a legal organization that has affairs, authority, duties, and functions in the field of employment in Malang.

Inhibiting Factors:

Nonoptimal use of information technology in data processing. The use of information technology in the Government is a demand for the implementation of effective, efficient, and accountable tasks as the embodiment of Good Governance Principles. The use of information technology in the data management will assist the data preparation of employee in Regional Employment Board that is factual and up to date. With such valid data, this will assist the Regional Employment Board in preparing the quality improvement of human resources through training and education activities. In this study, the use of information technology is not maximum in the data presentation. The media used is only a simple application in which still could not present the data related to the mobilization of employees. This means that the Regional Employment Board still encountered obstacles when presenting factual data related to employee mapping. For example, employees' placement and transfer have not been fully recorded with this existing application. Another obstacle is that there is no integrated system related to the management of employee data in each Regional Apparatus Organization. This is easier to record the presence of employees in an OPD. Besides that, there is no Training Needs Analysis (Analisis Kebutuhan Diklat or AKD) and Evaluation, Monitoring, and Alumni Utilization on Training (Monitoring dan Pendayagunaan Alumni Dampak Diklat or EMPADD). This non-optimal data will hamper the quality of the planning implemented by the Regional Employment Board.

Human resources do not meet the required specifications. Human factors in the implementation of organizational functions are very important because the work of an organization is strongly influenced by the implementing factor. When an organization's function does not meet the specifications of an affair, there will be the nonoptimal implementation of the function. Regional Employment Board that has the function of improving the quality of human resources in Malang regency is very dependent on the management. From the research, the personnel who manage the planning of training and education activities seems to be less optimal in carrying its function. The planning is still 
monotonous and the programs and activities undertaken tend to remain the same each year. There is no innovation in the type of training and education to improve the quality of human resources. Personnel who manage the planning should be able to read and predict related to the type of training and education including the materials for the quality improvement planning in Malang Regency. As stated by Danim (1996) in his book "Transformasi Sumber Daya Manusia" related to human resource improvement: Human resources quality is a resource that meets the criteria of physical and health quality, intellectual quality (knowledge and skills), and spiritual mental quality.

Inadequate Budget. Planning in the framework of quality improvement of human resources in Malang conducted by the Regional Employment Board will not be implemented and the expected results will not be obtained if it is not supported by the adequate budget. In the research, the planning of program and activity within the framework has been compiled based on the budget requirement plan, however, in the budget approval process; the budget ceiling is not suitable after it has been approved. There should be a policy in the budgeting system especially in the budget of human resources quality improvement in Malang. This is due to the fact that employee's performance gives a big impact on the performance of Local Government. In this case, the principle of consensus that is effective and efficient should be realized, meaning that the decision-making of a budget for particular program or activity must be executed carefully and able to produce a predetermined goal.

\section{CONCLUSION AND SUGGESTIONS}

Based on the results of the research, we can pull out a conclusion as follows:

The program of planning and activities on the Regional Employment Board have referred to the Regional Medium-Term Development Plan (Rencana Pembangunan Jangka Menengah Daerah or RPJMD) and Strategic Plan of Malang Regency especially in the plan of human resources (state apparatus) quality improvement in Malang. However, the plan is not optimal so that the achievement of program targets and activities is not in accordance with the intended purpose.

The planning of the development and improvement of human resources (state apparatus) has been implemented by the Regional Employment Board in accordance with the proposals of each Regional Apparatus Organization. However, the proposal is not optimal so that the apparatus who should follow the programs and activities related to the human resources improvement still cannot follow the program because the existing employment data in the Regional Apparatus Organization has not been properly managed.

In preparing the planning of personnel who have skills and capabilities to support the work of Regional Apparatus Organization, the analysis of employee needs has been preceded while the documents that have been prepared cannot be implemented completely because there are still political factors in realizing the results of the analysis.

Based on the discussion and conclusion above, the researchers suggest that:

There is a need to evaluate the programs and activities especially in synchronization with RPJMD and strategic plan of Malang so that the designed programs and activities are in accordance with the affairs, authorities, tasks, and functions of the Regional Employment Board and the goals can be realized.

A commitment from the Regional Employment Board to implement the results of the analysis is needed so that the plan can be arranged in accordance with existing needs.

It is necessary to evaluate the programs and activities specifically related to the improvement of the quality of the apparatus, thus, the evaluation can be done to improve the programs and activities and an innovation in supporting the achievement of the goals can be made.

An information technology in the field of employee data management needs to be built in each Regional Apparatus Organization with several servers located at the Regional Employment Board. By that, the program can be managed better and there will be an accountable employee data. 
There should be a budget policy in the field of apparatus quality development. If so, the future of professional and qualified apparatus in performing services to the community can be realized.

\section{REFERENCES}

1. Abdulwahab, Solichin. 1999. Analisis Kebijakan: Dari Formulasi ke Implementasi Kebijaksanaan Negara. Jakarta: PT Bumi Aksara.

2. Sedarmayanti (2009) Reformasi Administrasi Publik, Reformasi Birokrasi dan Kepemimpinan Masa Depan (Mewujudkan Pelayanan Prima dan Kepemerintahan Yang Baik). Refika ADITAMA

3. Daymon, Christine dan Immy Holloway. 2008. Metode-metode Riset Kualitatif dalam Public Relations \& Marketing Communications. Yogyakarta: Bentang.

4. Thompkins (2001), dalam Ambar Teguh Sulistiyani, Rosidah (2009) Manajemen Sumber Daya Manusia. Yogyakarta. Graha IImu.

5. Nawawi (2000), dalam Ambar Teguh Sulistiyani, Rosidah (2009) Manajemen Sumber Daya Manusia. Yogyakarta. Graha IImu. 